\title{
Indirect Bilirubin Measurement
}

National Cancer Institute

\section{Source}

National Cancer Institute. Indirect Bilirubin Measurement. NCI Thesaurus. Code C64483.

Bilirubin is in the insoluble form, unconjug ated bilirubin (indirect bilirubin).T he non-water soluble, free bilirubin does not react with sulfanilic acid at acidic $\mathrm{pH}$ to produce a red colored complex until an accelearator, alcohol, is added to the solution to perform a quantitative measurement of unconjug ated bilirubin levels. 